\title{
Article \\ Combining Methods to Better Estimate Total Fish Richness on Temperate Reefs: The Case of a Mediterranean Coralligenous Cliff
}

\author{
Alen Soldo ${ }^{1, *}$, Igor Glavičić ${ }^{1}$ and Marcelo Kovačić ${ }^{2} \mathbb{D}$ \\ 1 Department of Marine Studies, University of Split, 21000 Split, Croatia; igor.glavicic@gmail.com \\ 2 Natural History Museum Rijeka, Lorenzov Prolaz 1, 51000 Rijeka, Croatia; marcelo@prirodoslovni.com \\ * Correspondence: soldo@unist.hr
}

Citation: Soldo, A.; Glavičić, I.;

Kovačić, M. Combining Methods to

Better Estimate Total Fish Richness on

Temperate Reefs: The Case of a

Mediterranean Coralligenous Cliff. J.

Mar. Sci. Eng. 2021, 9, 670. https://

doi.org/10.3390/jmse9060670

Academic Editors: Anna Di Cosmo

and Gualtiero Basilone

Received: 21 May 2021

Accepted: 15 June 2021

Published: 18 June 2021

Publisher's Note: MDPI stays neutral with regard to jurisdictional claims in published maps and institutional affiliations.

Copyright: (c) 2021 by the authors. Licensee MDPI, Basel, Switzerland. This article is an open access article distributed under the terms and conditions of the Creative Commons Attribution (CC BY) license (https:// creativecommons.org/licenses/by/ $4.0 /)$

\begin{abstract}
Coralligenous habitat is considered as one of the most important special habitat types in the Mediterranean; however, due to its inaccessibility, little is known about it, although it is considered as one of the Mediterranean's richest habitats in terms of species. Due to a low number of studies, it was presumed that the richness of coralligenous fish assemblages is underestimated using traditional visual census methods which are not applicable to the deep, steep, and vertical slopes of coralligenous cliffs and do not capture exhaustively cryptobenthic species commonly found in this habitat. This paper aims at producing a more complete assessment of fish assemblages on a coralligenous cliff by combining different methods, particularly the deep vertical transect visual census and square with anesthetics method. A total of 76 fish species were recorded on a single coralligenous cliff, supporting the opinion that coralligenous cliffs are important Mediterranean biodiversity hotspots. The analysis of species traits between species recorded by the different methods showed how complementary they are to better describe species compositions. Hence, the result of this study demonstrates that the combined use of methods is essential for a more exhaustive description of the whole fish community structure and for accurate estimates of the abundance and diversity patterns, particularly in complex habitats such as coralligenous cliffs.
\end{abstract}

Keywords: coralligenous; fish assemblages; cryptobenthic; deep vertical transect; visual census; anesthetics

\section{Introduction}

The marine environment is extraordinarily diverse and made up of a large number of different marine habitats. They are identified by physical structures or specific environmental conditions. However, a large portion of the ocean remains unexplored, even the coastal habitats, particularly benthic assemblages thriving from $20 \mathrm{~m}$ depth down to the end of the continental shelf. Therefore, their distribution, ecological roles, threats, and status remain poorly known. In that zone, a typical Mediterranean habitat includes various coralligenous formations. Due to their inaccessibility, little is known about coralligenous habitats; however, they are considered as one of the Mediterranean's richest habitats in terms of species [1]. The ecological importance of coralligenous habitats and their scientific and biodiversity interest is recognized by international conventions (e.g., Barcelona Convention); hence, they can be considered one of the most important "special habitat types" that should be assessed under the Marine Strategy Framework Directive [2,3] through accurate monitoring plans [1].

Coralligenous formations are indicative of a circalittoral biocoenosis consisting of a three-dimensional biogenic build-up that forms a solid substrate primarily dominated by coralline algae [4]. Due to the variety of formations, there is no generally accepted definition; however, one of the most used defines coralligenous formations as a hard substrate of biogenic origin mainly produced by the accumulation of calcareous encrusting 
algae growing in dim light conditions [5]. They develop on both hard and soft bottoms, at 4 to $160 \mathrm{~m}$ of water depth, and adapt to low levels of nutrients and temperature from 10 to $23^{\circ} \mathrm{C}$ in waters with moderate hydrodynamics [4,5]. Although the morphology and inner structure of coralligenous formations depend on depth, topography, and the nature of prevailing algal builders, generally, the two geomorphotypes of coralligenous formations can be distinct: cliffs that are vertical or near-vertical walls from a steep littoral rock face, and banks that can be defined as flat frameworks with thickness ranging from 0.5 to $4 \mathrm{~m}$ mainly built over more or less horizontal substrate [4-6]. Coralligenous formations are composed of a wide number of species that create a complex habitat attracting variability of mobile species. Although sessile coralligenous assemblages have been studied, little is known about coralligenous fish assemblages [7]. The species richness of coralligenous fish assemblages was considered to be lower than that of shallow rocky habitats [8], but later studies showed that the species richness number per single coralligenous site is similar to fish assemblages of shallow rocky habitats [7]. Moreover, even those few studies presumed that the richness of coralligenous fish assemblages is underestimated using conventional visual census methods [9] and because of cryptobenthic species that are not recorded by visual census methods $[7,10]$. Such presumption was supported by the recent study of Soldo and Glavičić [11], who researched coralligenous habitat and suggested that underwater steep rocky coralligenous reefs have the highest fish species richness of any rocky habitat in the Mediterranean.

Monitoring methods change according to the objectives of each study. Although traditional methods using fishing gear have been used for the assessment of coralligenous fish assemblages [12], they are not applicable for steep cliffs. Currently, the most common observational method for reefs, in general, is an underwater visual census (UVC). A variety of UVC methods have been developed, but those focusing on reef fishes are mainly based on the use of SCUBA (Self-Contained Underwater Breathing Apparatus) divers conducting a survey, due to their better ability to search within such complex habitat compared to a stationary camera used by different remote underwater video methods $[11,13]$. However, as steep and vertical coralligenous reefs usually extend to depths deeper than $30 \mathrm{~m}$, the main disadvantage of conventional SCUBA diving is depth restriction because of safe diving considerations. The build-up of residual nitrogen in the diver's blood dictates short maximum dive times. Furthermore, as the dive depth increases, the allowable dive time decreases and requires a sufficient no-dive recovery period between dives [11]. The additional reason for depth restrictions in conventional SCUBA diving derives from limitations in commonly used existing technology [11]. Most divers worldwide use opencircuit diving gear with compressed air as breathing gas. Recently, an increasing number of divers have been experimenting with mixed-gas diving technology, including closed-circuit rebreather gear, to extend the depth limits of conventional SCUBA [14,15], but the high cost of equipment and requirement for extensive advanced training restricts such application to a small group of highly trained scientific divers [11].

In addition to diving related problems in applying UVC methods on coralligenous cliffs, an issue which impacts the quality of the assessment is the high small-scale heterogeneity of coralligenous outcrops that are very complex structures composed of several microhabitats [5]. Such habitat complexity usually impacts the quality of the standard UVC methods that can miss a large number of fish species, particularly those belonging to a cryptobenthic group [16-18], as defined by Kovačić et al. [18].

Soldo and Glavičić [11] recently reported six gobiid species within 51 fish species recorded from the surface to $50 \mathrm{~m}$ depth on the coralligenous cliff using the deep vertical transect (DVT) method. However, as the visibility of the species is a prerequisite of any visual census, bearing in mind the definition of cryptobenthic species by Kovačić et al. [18], it can be presumed that some species cannot be detected by the visual census, regardless of the method and technology used, as they are simply not visible at any moment.

Thus, it can be hypothesized that, for an improved assessment of fish assemblages on highly complex habitats, a combination of methods should be used. Considering the 
high complexity of the coralligenous cliffs and the recent results that suggest those habitats have the highest fish species richness of any rocky habitat in the Mediterranean [11], this paper aims to combine and compare methods for producing a complete assessment of fish species composition on a coralligenous cliff.

\section{Materials and Methods}

\subsection{Sampling Location}

The study was carried out at the underwater coralligenous cliff in the area of the island of Hvar channel (Figure 1), central eastern Adriatic $\left(43^{\circ} 14^{\prime} 02^{\prime \prime} \mathrm{N}, 16^{\circ} 34^{\prime} 29^{\prime \prime}\right.$ E). The cliff Smočiguzica is elliptically shaped with a truncated and oblique cone located $300 \mathrm{~m}$ from the coastline.

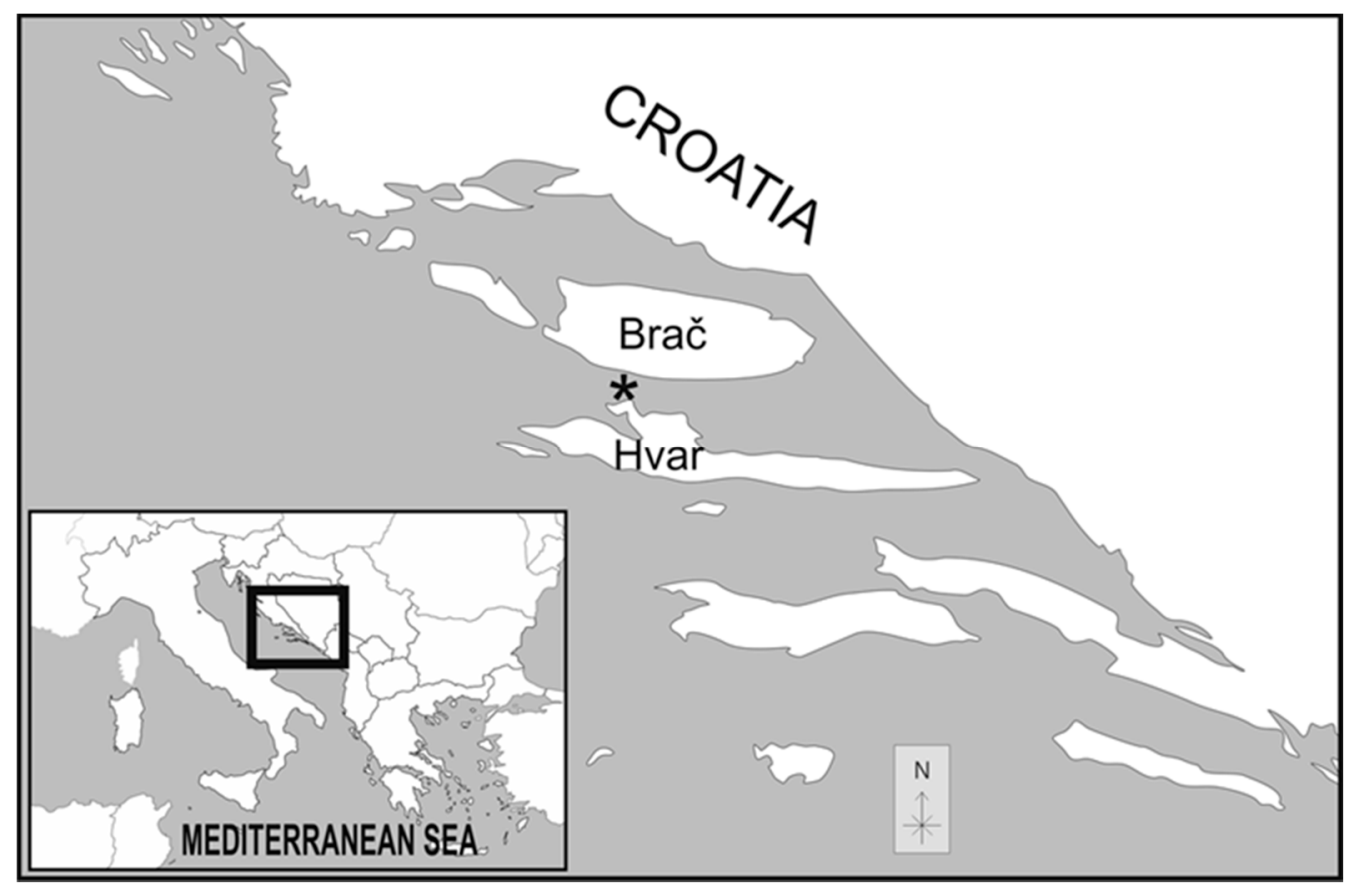

Figure 1. Location of the study area $\left(^{*}\right)$.

A large part of the cliff has a high slope with the highest point of $9.1 \mathrm{~m}$ and the deepest at $60.7 \mathrm{~m}$. The cover is coralligenous and it is surrounded by a sandy bottom. Apart from the depth changes, this single habitat on a single locality is surprisingly homogenous, since the steep inclination prevents the forming of the mixed bottom by sand sediment or the accumulation of multilayers of boulders and pebbles across the bedrock surface, except at the foot of the cliff at $60+\mathrm{m}$ depth. Sessile species covering each transect varied by depth and included both algae and animals, but the dominant species, apart from red algae, were green algae (Chlorophyta) Codium bursa (Olivi) C. Agardh 1817 (from 9 to $15 \mathrm{~m}$ ) and Flabellia petiolata (Turra) Nizamuddin 1987 (from 15 to $40 \mathrm{~m}$ ), bryozoan (Bryozoa) Pentapora fascialis (Pallas, 1766) (from 15 to $25 \mathrm{~m}$ ), ascidian (Ascidiacea) Halocynthia papillosa (Linnaeus, 1767) (from 20 to $45 \mathrm{~m}$ ), and corals (Anthozoa) Eunicella cavolini (Koch, 1887) (from 20 to $35 \mathrm{~m}$ ) and Parazoanthus axinellae (Schmidt, 1862) (from 30 to $60 \mathrm{~m}$ ). The shell debris sediment around the bottom of the cliff had rarely scattered surface fauna of biocoenosis of coastal detritical bottoms such as anemone (Anthozoa) Cerianthus membranaceus (Gmelin, 1791).

\subsection{Data Collection}

Two methods were used for sampling: the standard (DVT) method [11] and the square with anesthetics method (SAM) [18]. In addition, every diving expedition had some dive time not spent on the methods but on preparation and swimming from the boat to the studied surfaces and back, as well as the dive time and swim between two squares for 
SAM. The species recorded during that time and not recorded by any of the methods on any of the studied surfaces are separately listed in the results.

The diving expeditions with DVT method were performed on sunny days from midJune until the end of August 2020. The total number of performed transects was 216 . The DVT method is based on the use of $50 \mathrm{~m}$ long transects with $5 \mathrm{~m}$ height (being a vertical transect) as described in Soldo and Glavičić [11]. Two observers dive together, during which the first diver uses a high-definition (full HD) video camera and swims through the transect by browsing within it (S-type transect), varying in depth and angle and zooming when needed or notified by another diver of the presence of small or hidden fish individuals [11]. Due to the low light level at the dive depths, custom-made LED lights $2 \times 25 \mathrm{~W}$, producing a light temperature of $6400 \mathrm{~K}$ (sunlight color temperature), were used during video recording for easier post-identification of the species. Considering the high efficiency of the DVT method for the assessment of fish assemblages on vertical coralligenous cliffs [11], that method was used for collecting data on most of the fishes inhabiting or associating with the coralligenous cliff. Additionally, due to the wider base of the cliff, which was partly outside of the boundaries of the standard $50 \mathrm{~m}$ transect, a modified DVT method was used in a way that the length of the transect was not strictly $50 \mathrm{~m}$ but usually longer in order to sample the whole cliff area. Hence, the modified DVT method was applied mostly on areas down to $62 \mathrm{~m}$ depth, while transects shallower than $10 \mathrm{~m}$ were not sampled, as those areas were part of the standard transects. All DVT data were pooled together.

The SAM using diving and anesthetics (or alternatively ichthyocides) is the only method in general that can ensure efficient collection of truly cryptobenthic fishes [18]. According to Kovačić et al. [18], a cryptobenthic fish is a species (or a life history stage of a fish species) whose individuals exclusively or predominantly spend their lifetime in cryptobenthic microhabitats, i.e., in the restricted living spaces underneath the bottom surface of the substrate or biocover, with a physical barrier to open spaces. Hence, the same authors defined an epibenthic fish as a species or life history stage of a species that lives exclusively or predominantly on top of the bottom surface. Under this definition, cryptobenthic fishes should be distinguished from epibenthic fishes that use camouflage colors and shapes or shallowly bury themselves in the soft sediment surface. Moreover, cryptobenthic fishes should also be distinguished from any other predominantly epibenthic species or life history stages of species, which only seek shelter underneath the surface for a limited period of their total time, for example, after escape from predators, for resting, or for breeding. Otherwise, for example, all or almost all benthic gobiid species would be assigned to cryptobenthic fishes. Cryptobenthic fishes should also be distinguished from marine cave-dwelling fishes if the latter live epibenthically on top of the surface of a substrate or they swim free inside large cave spaces [18]. The SAM data were collected in the period 2012-2017 and were partially published for the data in 2013 [15] and for the data from autumn 2014 [19]. Considering the qualitative characteristic of the used data, the sample time interval length and the sample time difference from the DVT method did not influence the results. The total number of performed squares was 54, with each square having $1 \mathrm{~m}^{2}$ surface size. On all SAM diving expeditions, the method followed the protocol on squares, as described by Kovačić et al. [18], including the visual census of squares before anesthetic application. The anesthetic used was quinaldine diluted 1:15 with $96 \%$ ethanol and then mixed 1:5 in $750 \mathrm{~mL}$ bottles with seawater. Two bottles were usually used for a square, i.e., the total volume of the deployed quinaldine-ethanol solution was about $300 \mathrm{~mL} / \mathrm{m}^{2}$. Therefore, the SAM results consisted of the specimens observed by visual census on the square and of the specimens found only after deploying anesthetic, summarized separately.

In all methods, data and specimens were always collected by two SCUBA divers. Each dive started around 1:00 p.m., in order to have the best possible light conditions. DVT sampling ranged from the surface to $62 \mathrm{~m}$ depth, while SAM was performed from $15 \mathrm{~m}$ to $62 \mathrm{~m}$, since the coralligenous outcrops as a complex structure composed of several 
microhabitats were not present between the surface and $15 \mathrm{~m}$ depth. Depending on the depth of sampling, different breathing gases were used. For depths down to $50 \mathrm{~m}$, compressed air was used as a breathing gas, while, for deeper depths, trimix 20/30 was used as a bottom gas. During all dives, nitrox 50 was used as a decompression gas. Trimix enables safe diving at greater depths and nitrox enables a significant reduction in decompression time (a 50\% reduction compared to decompression with compressed air), as well as safer diving $[11,19]$. The change of breathing gases was performed at a depth of $21 \mathrm{~m}$, corresponding to oxygen partial pressure in nitrox of 1.6 bar.

Post-analysis of the video recorded by the DVT method was carried out on a $55^{\prime \prime}$ screen, using standard software that enables pausing, slow-motion viewing, and zooming of the images. Video analysis was conducted within $24 \mathrm{~h}$ of the dives (to use information still fresh in the memory of divers if necessary) with all fish identified and counted per species. The specimens collected by the square method were put to death after reaching the surface by a quinaldine overdose and stored in $70 \%$ ethanol solution. The preliminary field species identification of cryptobenthic specimens was later rechecked in the lab.

\subsection{Data Analysis}

The species compositions of the DVT method and SAM were incomparable quantitatively due to differences in surface size, time, and number of samples between methods. Therefore, the species compositions were compared qualitatively. The similarity of DVT and SAM qualitative species compositions was calculated by the Jaccard/Tanimoto coefficient, a binary similarity coefficient which is the ratio of the samples' intersection to their union. For each species observed by the DVT method, the frequency of occurrence was calculated according to the number of dives when the species was recorded divided by the total number of dives. Similarly, the species frequency of occurrence on SAM squares was calculated as the number of squares with species present divided by the total number of performed squares. The values of frequencies of occurrence were also not comparable as absolute values between methods, considering the large difference in the surface size of more than two orders of magnitude between DVT transects and SAM squares, which causes more frequent species occurrences on DVT transects. Therefore, the ranks were compared, and the significance of association between the ranked orders of species frequency of occurrence from DVT transects and SAM squares was tested by the nonparametric Kendall coefficient of rank correlation, $\tau$ [20]. The traits of species occurring in the DVT and SAM samples were compared. The species traits were divided into categories as follows: maximum size (very small fish $>6 \mathrm{~cm}$ total length (TL), small fish $>6-10 \mathrm{~cm}$ TL, medium sized fish > 10-50 cm TL, large fishes $>50 \mathrm{~cm}$ (TL); relationship to the bottom (pelagic fish, benthopelagic fish, hyperbenthic, epibenthic, cryptobenthic); relationship to the reef (reef-associated, occasional), trophic level (2-2.99, 3-3.99, 4-4.7), catchability by commercial and recreational fishing tools (catchable, non-catchable), tangible species vs. elusive species, measured indirectly by the century of description (18th, 19th, 20th, 21st), and taxonomy (by the taxon level of orders). Maximum size and trophic level followed Froese and Pauly [21]. Trophic levels were estimated as described in Pauly et al. [22]. Trophic levels in aquatic environments range from 2 for herbivores and detritivores to 5.5 for specialized predators of marine mammals; for fishes in particular, the trophic levels generally range from 2 for the detritus feeding species to 4.7 for piscivorous species [22]. The relationship to the bottom, the relationship to the reef, and catchability were estimated from the species data in Dulčić and Kovačić [23]. The taxonomy and the century of description for each species followed Van der Laan et al. [24]. The significance of differences in each trait was tested by the Fisher exact test [25]. The Fisher exact test, despite being conservative, is more appropriate than other tests of independence for the contingency tables with some cell counts lower than 5 [25]. Statistical analyses were performed in PAST version 2.17c [26]. 


\section{Results}

Total observed fish richness on this single reef with a homogenous habitat of steep bedrock was 76 fish species, with 56 of them recorded by DVT, 28 recorded by SAM, and five randomly noticed during DVT and SAM divings, but outside of the studied area and applied methods (Table 1). The species composition overlap between DVT and SAM was just 13 species. Therefore, visual census on large transects, as the main method, was able to capture $73.7 \%$ of total fish species richness on locality, while SAM recorded $36.8 \%$ of the total fish species richness on locality. Only $17.1 \%$ of all species overlapped between DVT and SAM (Table 1). The DVT and SAM low overlap in species composition represented about $1 / 4$ of DVT species and about $1 / 2$ of SAM species. The Jaccard/Tanimoto coefficient of similarity between DVT and SAM species composition was low, 0.13 , showing low similarity in species composition. The DVT method recorded 45 reef associated species and 11 occasional species, the latter being defined as mainly active and more mobile predators that use the underwater cliff as an important feeding area (Table 1). Within the total observed fish richness, $19.7 \%$ of fishes were recorded exclusively by SAM. From 28 SAM species, 13 were observed visually on squares, and 22 were driven out by anesthetic; therefore, seven species were ambivalent (i.e., epibenthic/cryptobenthic) in relation to the bottom and 15 were exclusively cryptobenthic (Table 1). Only five species of total fish species richness were recorded outside of the transects and squares of both methods and were randomly recorded during diving, three of them being tidal blenniid species recorded at the start or end of diving expeditions. The remaining two species are real inhabitants of infralittoral reefs, while the lack of regular occurrence of L. candolii could be explained by the absence of multilayers of boulders and pebbles on a vertical cliff, and the lack of regular occurrence of $S$. ocellatus could be explained by the absence of high vegetation or highly structured shallow rocky bottom. The ranked orders of species frequency of occurrence of each method showed a general mismatch between the two methods (Table 2). The Kendall coefficient of rank correlation showed an absence of a significant association between the ranked orders of species frequency of occurrence between DVT and SAM $(\tau=-0.119$, $p=0.127)$. The species recorded by the DVT method and SAM show a significant difference in all species trait compositions (Table 3). The DVT recorded species significantly larger and less associated with the bottom than SAM, with the DVT species size modal value at $10-50 \mathrm{~cm}$ total length vs. the SAM species size modal values at $\leq 6 \mathrm{~cm}$ total length (Table 3). Hyperbenthic species were the most numerous DVT species vs. cryptobenthic as the most numerous SAM species (Table 3). The DVT species composition was significantly different from the SAM method in relation to the reef, with 11 occasional species recorded, while none of the occasional species were found by SAM (Table 3). The DVT recorded species had significantly different trophic levels than the SAM recorded species, having more omnivorous and herbivorous species than SAM, as well as species with a trophic level above 4, suggesting a wider trophic range, although the modal value for both groups was at 3-3.99 (Table 3). The DVT species composition was significantly different from the SAM species composition in exposure to fishing tools, having prevailingly species catchable by fishing tools, while the majority of the SAM species were not possible to collect by any conventional fishing method (Table 3). SAM also mostly recorded species described later (19th, 20th, 21st), which was a significantly different composition by century of description to DVT species which were mostly described in the 18th century (Table 3). SAM had significantly different composition by taxonomy on the taxon level of order, compared to DVT species composition, with the species richest order being Gobiiformes, with 14 species, versus the species richest order Perciformes in the DVT species composition, with 31 species. 
Table 1. Species recorded by DVT method: + reef-associated species or species which permanently occupy the coralligenous surface or habitats around the reef base (sandy), (+) occasional species or species which are mainly active and more mobile predators that use reef as feeding areas. Species recorded by SAM: + visually observed specimens on $1 \mathrm{~m}^{2}$ squares, * specimens collected with anesthetics on $1 \mathrm{~m}^{2}$ squares. Species from DVT, modified DVT, and SAM dives visually noticed during those dives, but not recorded by the methods, marked with + in a separate column.

\begin{tabular}{|c|c|c|c|c|}
\hline Family & Method/Recorded Species & $\begin{array}{l}\text { DVT and Modified } \\
\text { DVT Visually } \\
\text { Observed Species on } \\
\text { Transects }\end{array}$ & $\begin{array}{l}\text { SAM Recorded } \\
\text { Species on } 1 \mathrm{~m}^{2} \\
\text { Squares }\end{array}$ & $\begin{array}{l}\text { Species from DVT, } \\
\text { Modified DVT, and } \\
\text { SAM Dives Visually } \\
\text { Noticed during Dives } \\
\text { But Not Recorded by } \\
\text { the Methods }\end{array}$ \\
\hline Apogonidae & $\begin{array}{l}\text { Apogon imberbis } \\
\text { (Linnaeus, 1758) }\end{array}$ & + & & \\
\hline \multirow[t]{5}{*}{ Blennidae } & $\begin{array}{l}\text { Microlipophrys canevae } \\
\text { (Vinciguerra, 1880) }\end{array}$ & & & + \\
\hline & $\begin{array}{l}\text { Microlipophrys nigriceps } \\
\text { (Vinciguerra, 1883) }\end{array}$ & & * & \\
\hline & $\begin{array}{c}\text { Parablennius incognitus (Bath, } \\
\text { 1968) }\end{array}$ & & & + \\
\hline & Parablennius rouxi (Cocco, 1833$)$ & + & * & \\
\hline & $\begin{array}{l}\text { Parablennius zvonimiri } \\
\text { (Kolombatović, 1892) }\end{array}$ & & & + \\
\hline \multirow[t]{3}{*}{ Carangidae } & Lichia amia (Linnaeus, 1758) & $(+)$ & & \\
\hline & Seriola dumerili (Risso, 1810) & $(+)$ & & \\
\hline & $\begin{array}{c}\text { Trachurus trachurus } \\
\text { (Linnaeus, 1758) }\end{array}$ & $(+)$ & & \\
\hline Congridae & Conger conger (Linnaeus, 1758) & + & & \\
\hline Coryphaenidae & $\begin{array}{c}\text { Coryphaena hippurus } \\
\text { Linnaeus, } 1758\end{array}$ & $(+)$ & & \\
\hline Gadidae & $\begin{array}{l}\text { Merlangius merlangus } \\
\text { (Linnaeus, 1758) }\end{array}$ & + & & \\
\hline \multirow[t]{2}{*}{ Gobiesocidae } & $\begin{array}{c}\text { Apletodon incognitus Hofrichter } \\
\text { and Patzner, } 1997\end{array}$ & & * & \\
\hline & Lepadogaster candolii Risso, 1810 & & & + \\
\hline \multirow[t]{12}{*}{ Gobiidae } & $\begin{array}{l}\text { Chromogobius zebratus } \\
\text { (Kolombatović, 1891) }\end{array}$ & & * & \\
\hline & $\begin{array}{l}\text { Corcyrogobius liechtensteini } \\
\text { (Kolombatović, 1891) }\end{array}$ & & * & \\
\hline & $\begin{array}{l}\text { Didogobius splechtnai Ahnelt } \\
\text { and Patzner, } 1995\end{array}$ & & * & \\
\hline & $\begin{array}{c}\text { Gammogobius steinitzi } \\
\text { Bath, } 1971\end{array}$ & & * & \\
\hline & Gobius auratus Risso, 1810 & + & $+*$ & \\
\hline & Gobius cruentatus Gmelin, 1789 & + & & \\
\hline & Gobius fallax Sarato, 1889 & & * & \\
\hline & Gobius geniporus & & & \\
\hline & Valenciennes, 1837 & + & & \\
\hline & $\begin{array}{c}\text { Gobius incognitus Kovačić and } \\
\text { Šanda, } 2016\end{array}$ & + & & \\
\hline & $\begin{array}{c}\text { Gobius kolombatovici Kovačić } \\
\text { and Miller, } 2000\end{array}$ & + & $+^{*}$ & \\
\hline & $\begin{array}{c}\text { Gobius vittatus } \\
\text { Vinciguerra, } 1883\end{array}$ & & $+^{*}$ & \\
\hline
\end{tabular}


Table 1. Cont.

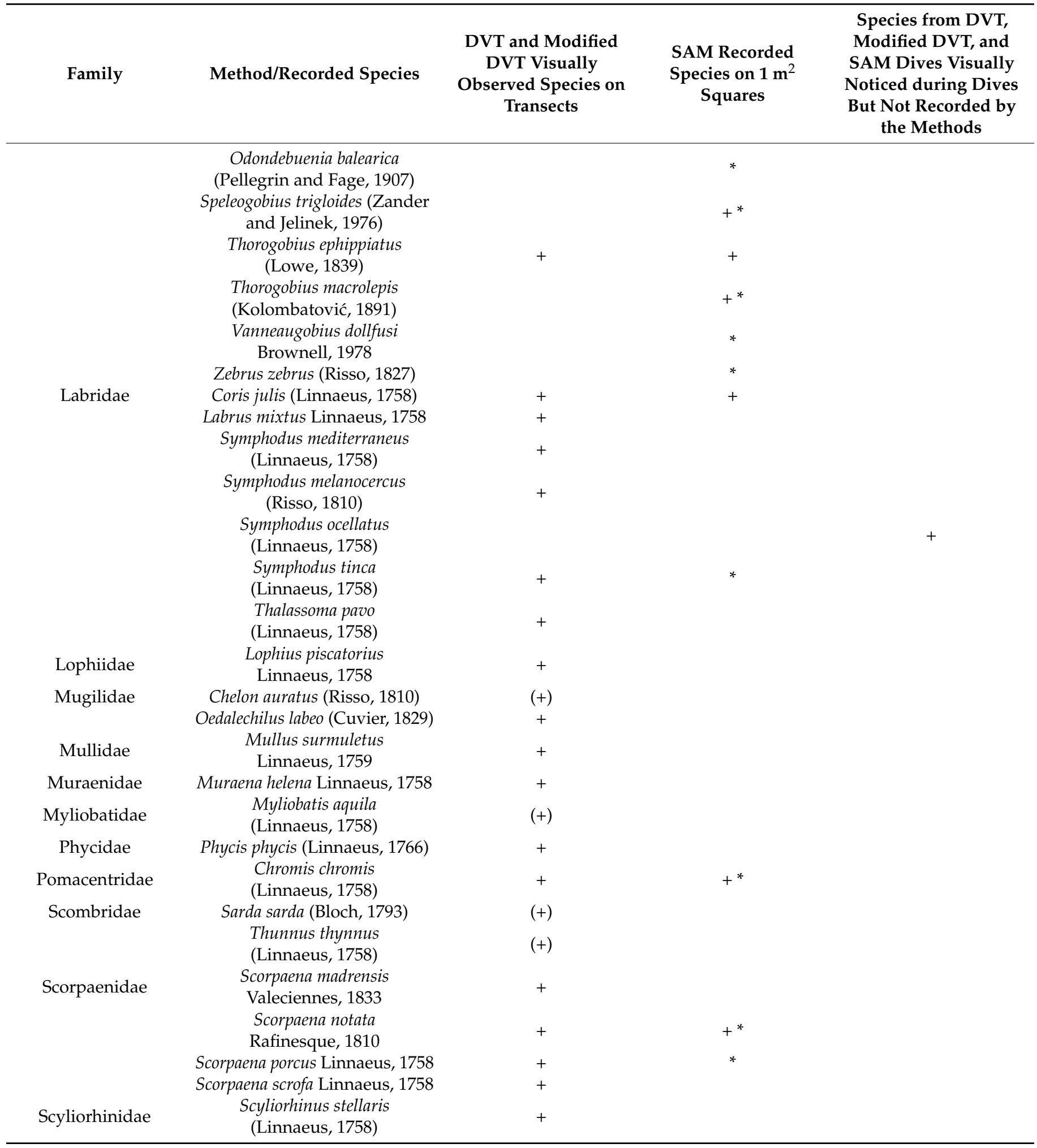


Table 1. Cont.

\begin{tabular}{|c|c|c|c|c|}
\hline Family & Method/Recorded Species & $\begin{array}{l}\text { DVT and Modified } \\
\text { DVT Visually } \\
\text { Observed Species on } \\
\text { Transects }\end{array}$ & $\begin{array}{l}\text { SAM Recorded } \\
\text { Species on } 1 \mathrm{~m}^{2} \\
\text { Squares }\end{array}$ & $\begin{array}{c}\text { Species from DVT, } \\
\text { Modified DVT, and } \\
\text { SAM Dives Visually } \\
\text { Noticed during Dives } \\
\text { But Not Recorded by } \\
\text { the Methods }\end{array}$ \\
\hline \multirow[t]{4}{*}{ Scorpaenidae } & $\begin{array}{l}\text { Scorpaena madrensis } \\
\text { Valeciennes, } 1833\end{array}$ & + & & \\
\hline & $\begin{array}{l}\text { Scorpaena notata } \\
\text { Rafinesque, } 1810\end{array}$ & + & $+*$ & \\
\hline & Scorpaena porcus Linnaeus, 1758 & + & * & \\
\hline & Scorpaena scrofa Linnaeus, 1758 & + & & \\
\hline Scyliorhinidae & $\begin{array}{l}\text { Scyliorhinus stellaris } \\
\text { (Linnaeus, 1758) }\end{array}$ & + & & \\
\hline \multirow[t]{4}{*}{ Serranidae } & $\begin{array}{l}\text { Epinephelus costae } \\
\text { (Steindachner, 1878) }\end{array}$ & + & & \\
\hline & $\begin{array}{l}\text { Epinephelus marginatus } \\
\text { (Lowe, 1834) }\end{array}$ & + & & \\
\hline & $\begin{array}{l}\text { Serranus cabrilla } \\
\text { (Linnaeus, 1758) } \\
\text { Serranus hepatus } \\
\text { (Linnaeus, 1758) }\end{array}$ & $\begin{array}{l}+ \\
+\end{array}$ & + & \\
\hline & Serranus scriba (Linnaeus, 1758) & + & + & \\
\hline Soleidae & $\begin{array}{c}\text { Synapturichthys kleinii } \\
\text { (Risso, 1827) }\end{array}$ & + & & \\
\hline \multirow[t]{12}{*}{ Sparidae } & Boops boops (Linnaeus, 1758) & + & & \\
\hline & $\begin{array}{c}\text { Diplodus annularis } \\
\text { (Linnaeus, 1758) }\end{array}$ & + & + & \\
\hline & $\begin{array}{l}\text { Diplodus puntazzo } \\
\text { (Walbaum, 1792) }\end{array}$ & + & & \\
\hline & $\begin{array}{c}\text { Diplodus vulgaris (Geoffroy } \\
\text { St. Hilaire, 1817) }\end{array}$ & + & & \\
\hline & $\begin{array}{l}\text { Lithognathus mormyrus } \\
\text { (Linnaeus, 1758) }\end{array}$ & + & & \\
\hline & $\begin{array}{l}\text { Oblada melanura } \\
\text { (Linnaeus, 1758) }\end{array}$ & + & & \\
\hline & Sarpa salpa (Linnaeus, 1758) & + & & \\
\hline & Sparus aurata Linnaeus, 1758 & + & & \\
\hline & $\begin{array}{c}\text { Spicara flexuosa } \\
\text { Rafinesque, } 1810\end{array}$ & + & & \\
\hline & Spicara maena (Linnaeus, 1758) & + & & \\
\hline & Spicara smaris (Linnaeus, 1758) & + & & \\
\hline & $\begin{array}{l}\text { Spondyliosoma cantharus } \\
\text { (Linnaeus, 1758) }\end{array}$ & + & & \\
\hline Sphyraenidae & $\begin{array}{l}\text { Sphyraena sphyraena } \\
\text { (Linnaeus, 1758) }\end{array}$ & $(+)$ & & \\
\hline Triglidae & $\begin{array}{l}\text { Chelidonichthys lastoviza } \\
\text { (Bonnaterre, 1788) }\end{array}$ & $(+)$ & & \\
\hline \multirow[t]{3}{*}{ Tripterygiidae } & $\begin{array}{c}\text { Tripterygion delaisi Cadenat and } \\
\text { Blanche, } 1971\end{array}$ & + & + & \\
\hline & $\begin{array}{c}\text { Tripterygion melanurum } \\
\text { Guichenot, } 1850\end{array}$ & & * & \\
\hline & $\begin{array}{c}\text { Tripterygion tripteronotum } \\
\text { (Risso, 1810) }\end{array}$ & & * & \\
\hline
\end{tabular}


Table 2. The frequencies of occurrence for species recorded by the DVT and SAM methods.

\begin{tabular}{|c|c|c|c|}
\hline Species & $\begin{array}{c}\text { DVT and Modifed DVT } \\
\text { Frequency of Occurence (\%) }\end{array}$ & Species & $\begin{array}{l}\text { SAM Frequency of } \\
\text { Occurence }(\%)\end{array}$ \\
\hline Parablennius rouxi (Cocco, 1833) & 100.00 & $\begin{array}{l}\text { Corcyrogobius liechtensteini } \\
\text { (Kolombatović, 1891) }\end{array}$ & 68.50 \\
\hline Spicara flexuosa Rafinesque, 1810 & 100.00 & Gobius auratus Risso, 1810 & 61.10 \\
\hline Spicara smaris (Linnaeus, 1758) & 100.00 & $\begin{array}{c}\text { Odondebuenia balearica (Pellegrin } \\
\text { and Fage, 1907) }\end{array}$ & 48.10 \\
\hline Gobius auratus Risso, 1810 & 100.00 & Coris julis (Linnaeus, 1758) & 27.80 \\
\hline Gobius cruentatus Gmelin, 1789 & 100.00 & $\begin{array}{c}\text { Didogobius splechtnai Ahnelt and } \\
\text { Patzner, } 1995\end{array}$ & 20.40 \\
\hline Coris julis (Linnaeus, 1758) & 100.00 & Parablennius rouxi (Cocco, 1833) & 18.50 \\
\hline Labrus mixtus Linnaeus, 1758 & 100.00 & $\begin{array}{l}\text { Chromogobius zebratus } \\
\text { (Kolombatović, 1891) }\end{array}$ & 14.80 \\
\hline $\begin{array}{l}\text { Symphodus mediterraneus } \\
\text { (Linnaeus, 1758) }\end{array}$ & 100.00 & Chromis chromis (Linnaeus, 1758) & 14.80 \\
\hline $\begin{array}{l}\text { Symphodus melanocercus } \\
\text { (Risso, 1810) }\end{array}$ & 100.00 & $\begin{array}{l}\text { Thorogobius macrolepis } \\
\text { (Kolombatović, 1891) }\end{array}$ & 9.30 \\
\hline $\begin{array}{l}\text { Symphodus tinca } \\
\text { (Linnaeus, 1758) }\end{array}$ & 100.00 & $\begin{array}{c}\text { Vanneaugobius dollfusi Brownell, } \\
1978\end{array}$ & 9.30 \\
\hline Chromis chromis (Linnaeus, 1758) & 100.00 & Zebrus zebrus (Risso, 1827) & 9.30 \\
\hline $\begin{array}{c}\text { Scorpaena madrensis Valeciennes, } \\
1833\end{array}$ & 100.00 & Gobius vittatus Vinciguerra, 1883 & 7.40 \\
\hline $\begin{array}{c}\text { Scorpaena notata Rafinesque, } \\
1810\end{array}$ & 100.00 & $\begin{array}{c}\text { Scorpaena notata Rafinesque, } \\
1810\end{array}$ & 7.40 \\
\hline Scorpaena porcus Linnaeus, 1758 & 100.00 & $\begin{array}{c}\text { Gobius kolombatovici Kovačić and } \\
\text { Miller, } 2000\end{array}$ & 5.60 \\
\hline $\begin{array}{l}\text { Scyliorhinus stellaris } \\
\text { (Linnaeus, 1758) }\end{array}$ & 100.00 & $\begin{array}{c}\text { Thorogobius ephippiatus } \\
\text { (Lowe, 1839) }\end{array}$ & 5.60 \\
\hline Serranus cabrilla (Linnaeus, 1758) & 100.00 & $\begin{array}{l}\text { Microlipophrys nigriceps } \\
\text { (Vinciguerra, 1883) }\end{array}$ & 3.70 \\
\hline Serranus scriba (Linnaeus, 1758) & 100.00 & Gammogobius steinitzi Bath, 1971 & 3.70 \\
\hline Boops boops (Linnaeus, 1758) & 100.00 & $\begin{array}{l}\text { Speleogobius trigloides (Zander } \\
\text { and Jelinek, 1976) }\end{array}$ & 3.70 \\
\hline $\begin{array}{l}\text { Diplodus annularis } \\
\text { (Linnaeus, 1758) }\end{array}$ & 100.00 & Serranus scriba (Linnaeus, 1758) & 3.70 \\
\hline $\begin{array}{l}\text { Diplodus puntazzo } \\
\text { (Walbaum, 1792)) }\end{array}$ & 100.00 & $\begin{array}{c}\text { Diplodus annularis } \\
\text { (Linnaeus, 1758) }\end{array}$ & 3.70 \\
\hline $\begin{array}{c}\text { Diplodus vulgaris (Geoffroy } \\
\text { St. Hilaire, 1817) }\end{array}$ & 100.00 & $\begin{array}{c}\text { Apletodon incognitus Hofrichter } \\
\text { and Patzner, } 1997\end{array}$ & 1.90 \\
\hline Gobius fallax Sarato, 1889 & 94.44 & $\begin{array}{c}\text { Gobius geniporus } \\
\text { Valenciennes, } 1837\end{array}$ & 1.90 \\
\hline $\begin{array}{c}\text { Gobius incognitus Kovačić and } \\
\text { Šanda, } 2016\end{array}$ & 94.44 & $\begin{array}{l}\text { Symphodus tinca } \\
\text { (Linnaeus, 1758) }\end{array}$ & 1.90 \\
\hline Scorpaena scrofa Linnaeus, 1758 & 94.44 & Scorpaena porcus Linnaeus, 1758 & 1.90 \\
\hline $\begin{array}{c}\text { Tripterygion delaisi Cadenat \& } \\
\text { Blanche, } 1971\end{array}$ & 94.44 & Serranus cabrilla (Linnaeus, 1758) & 1.90 \\
\hline $\begin{array}{l}\text { Gobius kolombatovici Kovačić and } \\
\text { Miller, } 2000\end{array}$ & 88.88 & $\begin{array}{l}\text { Tripterygion delaisi Cadenat and } \\
\text { Blanche, } 1971\end{array}$ & 1.90 \\
\hline $\begin{array}{l}\text { Serranus hepatus } \\
\text { (Linnaeus, 1758) }\end{array}$ & 88.88 & $\begin{array}{c}\text { Tripterygion melanurum } \\
\text { Guichenot, } 1850\end{array}$ & 1.90 \\
\hline Spicara maena (Linnaeus, 1758) & 66.66 & $\begin{array}{c}\text { Tripterygion tripteronotum } \\
\text { (Risso, 1810) }\end{array}$ & 1.90 \\
\hline Conger conger (Linnaeus, 1758) & 66.66 & & \\
\hline Phycis phycis (Linnaeus, 1766) & 66.66 & & \\
\hline Sarpa salpa (Linnaeus, 1758) & 61.11 & & \\
\hline Sparus aurata Linnaeus, 1758 & 61.11 & & \\
\hline Apogon imberbis (Linnaeus, 1758) & 55.55 & & \\
\hline $\begin{array}{l}\text { Thorogobius ephippiatus } \\
\text { (Lowe, 1839) }\end{array}$ & 55.55 & & \\
\hline
\end{tabular}


Table 2. Cont

\begin{tabular}{|c|c|c|c|}
\hline Species & $\begin{array}{c}\text { DVT and Modifed DVT } \\
\text { Frequency of Occurence (\%) }\end{array}$ & Species & $\begin{array}{l}\text { SAM Frequency of } \\
\text { Occurence }(\%)\end{array}$ \\
\hline $\begin{array}{l}\text { Epinephelus marginatus } \\
\text { (Lowe, 1834) }\end{array}$ & 55.55 & & \\
\hline $\begin{array}{l}\text { Oblada melanura } \\
\text { (Linnaeus, 1758) }\end{array}$ & 55.55 & & \\
\hline $\begin{array}{c}\text { Mullus surmuletus } \\
\text { (Linnaeus, 1758) }\end{array}$ & 50.00 & & \\
\hline Muraena helena Linnaeus, 1758 & 44.44 & & \\
\hline $\begin{array}{c}\text { Epinephelus costae } \\
\text { (Steindachner, 1878) }\end{array}$ & 44.44 & & \\
\hline $\begin{array}{l}\text { Lithognathus mormyrus } \\
\text { (Linnaeus, 1758) }\end{array}$ & 44.44 & & \\
\hline $\begin{array}{l}\text { Spondyliosoma cantharus } \\
\quad \text { (Linnaeus, 1758) }\end{array}$ & 44.44 & & \\
\hline $\begin{array}{l}\text { Merlangius merlangus } \\
\text { (Linnaeus, 1758) }\end{array}$ & 38.88 & & \\
\hline Thalassoma pavo (Linnaeus, 1758) & 38.88 & & \\
\hline Oedalechilus labeo (Cuvier, 1829) & 16.66 & & \\
\hline Seriola dumerili (Risso, 1810) & 11.11 & & \\
\hline $\begin{array}{l}\text { Lophius piscatorius } \\
\text { Linnaeus, } 1758\end{array}$ & 11.11 & & \\
\hline Chelon auratus (Risso, 1810) & 11.11 & & \\
\hline $\begin{array}{l}\text { Myliobatis aquila } \\
\text { (Linnaeus, 1758) }\end{array}$ & 11.11 & & \\
\hline $\begin{array}{l}\text { Chelidonichthys lastoviza } \\
\text { (Bonnaterre, 1788) }\end{array}$ & 11.11 & & \\
\hline Lichia amia (Linnaeus, 1758) & 5.55 & & \\
\hline $\begin{array}{c}\text { Trachurus trachurus } \\
\text { (Linnaeus, 1758) }\end{array}$ & 5.55 & & \\
\hline $\begin{array}{l}\text { Coryphaena hippurus } \\
\text { Linnaeus, } 1758\end{array}$ & 5.55 & & \\
\hline Sarda sarda (Bloch, 1793) & 5.55 & & \\
\hline $\begin{array}{l}\text { Thunnus thynnus } \\
\text { (Linnaeus, 1758) }\end{array}$ & 5.55 & & \\
\hline $\begin{array}{l}\text { Synapturichthys kleinii } \\
\text { (Risso, 1827) }\end{array}$ & 5.55 & & \\
\hline $\begin{array}{l}\text { Sphyraena sphyraena } \\
\text { (Linnaeus, 1758) }\end{array}$ & 5.55 & & \\
\hline
\end{tabular}

Table 3. The frequencies of species traits for species recorded by the DVT method and SAM.

\begin{tabular}{ccc}
\hline Trait/Number of Species & DVT Recorded Species & SAM Recorded Species \\
\hline (a) Maximum size & 11 & 0 \\
Very small fish $\leq 6 \mathrm{~cm}$ total length (TL) & 8 & 4 \\
Small fish $>6-10 \mathrm{~cm}$ TL & 9 & 32 \\
Medium sized fish $10-50 \mathrm{~cm}$ TL & 0 & 20 \\
Large fishes $>50 \mathrm{~cm}$ TL & & \\
Fisher's exact test $p$-value & & \\
(b) Relationship to the bottom & 5 & 0 \\
Pelagic fish & 6 & 0 \\
Benthopelagic species & 25 & 6 \\
Hyperbenthic species & 19 & 10 \\
Epibenthic species & 1 & 12 \\
Cryptobenthic species & & $<0.001$ \\
Fisher's exact test $p$-value & & \\
\hline
\end{tabular}


Table 3. Cont.

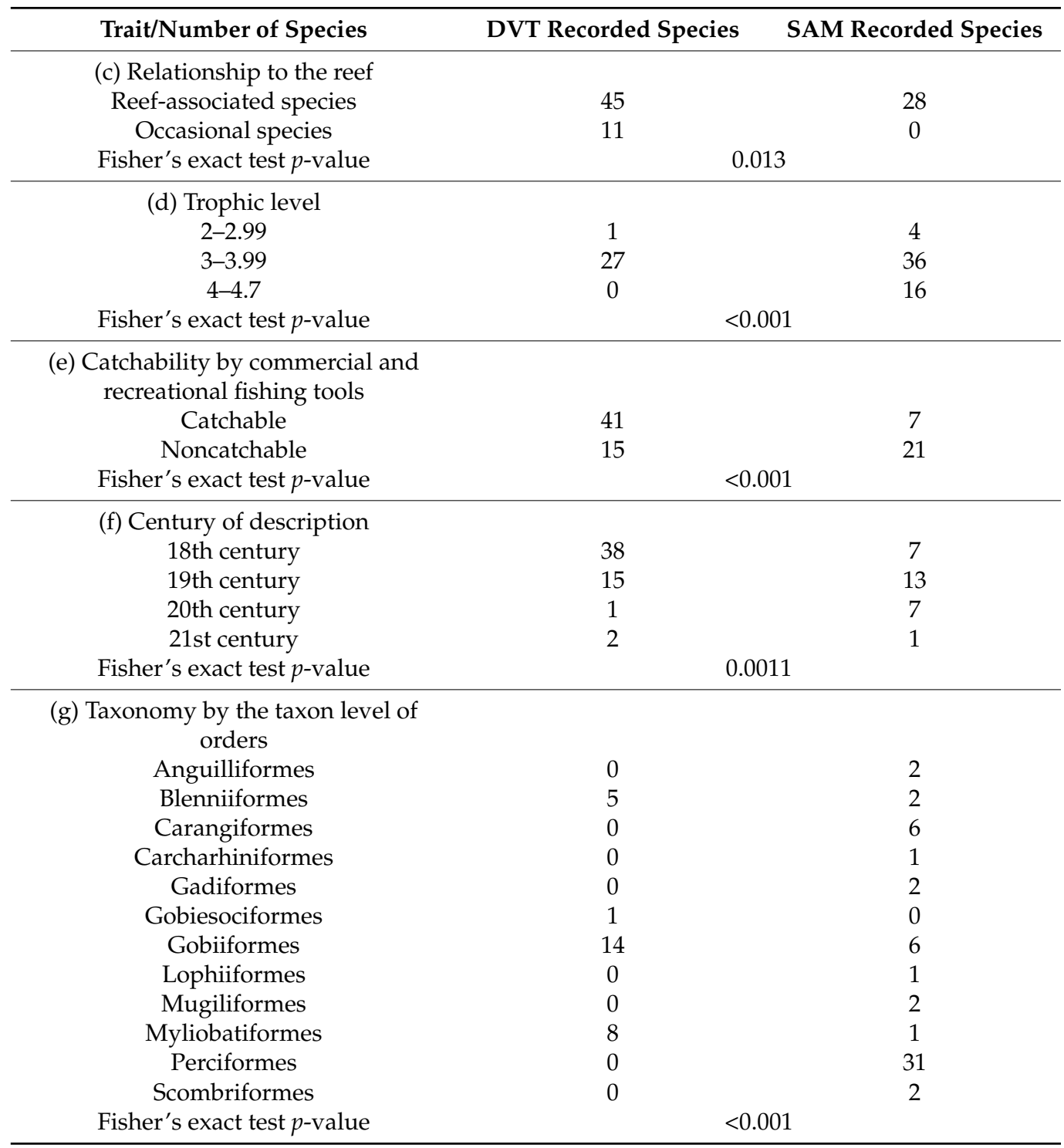

\section{Discussion}

La Mesa et al. [27] compared fish richness in different locations and habitats of the Mediterranean including sandy habitat to Posidonia oceanica beds and rocky reefs. Overall, they recorded 59 species with rocky habitat being the richest, having a total of 43 species. Higher species richness on rocky reefs can be explained by habitat structure, which is recognized as one of the factors likely to explain the variability of Mediterranean fish assemblages [28]. García-Charton et al. [28] presumed that higher heterogeneity and complexity of habitat will increase the number of species and individuals. Nevertheless, despite coralligenous habitat complexity, the species richness of coralligenous fish assemblages was previously considered to be lower than that of shallow rocky habitats [8]. However, Piazzi [7] recorded 61 fish species in a coralligenous habitat, but at 14 different locations, where the number of species per location varied between 35 and 46. Thus, Piazzi [7] concluded that the mean value of species number per single coralligenous site is similar to fish assemblages of shallow rocky habitats. Hence, it was presumed that the richness of coralligenous fish assemblages was underestimated using visual census methods which are not applicable to the deeper, steep, and vertical slopes of Mediterranean coralligenous cliffs [9] and do not exhaustively record cryptobenthic species that are commonly found in this habitat $[7,10]$. Consequently, Soldo and Glavičić [11] developed a new transect 
method for coralligenous habitat to an extended depth of $50 \mathrm{~m}$ and recorded a total of 51 species, thus suggesting that underwater steep rocky coralligenous reefs have the highest fish biodiversity and population density of any rocky habitat in the Mediterranean. The same conclusion can be derived from the results of this study, as the total of 76 fish species recorded on a single coralligenous cliff certainly supports the presumption about coralligenous cliffs as Mediterranean biodiversity hotspots.

Although this study was conducted up to $62 \mathrm{~m}$ of depth, the use of new diving techniques to extend the depth limits of conventional SCUBA worked well with sampling methodologies, which demonstrates that usual depth restrictions in conventional SCUBA diving, derived from the use of the open-circuit diving gear with compressed air as breathing gas, could be surpassed by mixed-gas diving technology.

Despite discussed limitations, visual census on large transects remains the crucial method for the assessment of fish assemblages, especially on simple and/or relatively large habitats, being able to capture the majority of species. However, results from this study show that, for more complex habitats, such as coralligenous cliffs, a significant portion of total species richness, about one-quarter, is not recorded by the transect method. Although the DVT method, both standard and modified, recorded a significant portion of small body size species, owing to advances in video high-resolution technology and appropriate sampling technique, it is obvious that some species cannot be detected by any method of visual census, because they entirely or predominantly spend their lifetime hidden and, thus, not visible. Therefore, in such cases, the SAM method was shown to be a necessary component in total species richness estimation, since nearly one-fifth of total species richness was recorded only by SAM. The DVT and SAM poor overlap in species composition showed that these methods are truly complementary and should be applied together in studying total reef fish diversity. The ranked orders of species frequency of occurrence of each method showed a general mismatch and no significant association between the two methods (Table 2). Until now, combined methods for estimating total fish species richness of a single habitat have not been used, but some studies have compared the effectiveness of the visual census and the anesthetic/ichthyocide census techniques for determining richness of cryptobenthic species [29-31]. The reported portion of cryptobenthic species underestimated by the visual census method from those studies is in accordance with the results of this study.

While the higher effectiveness of combined methods versus the visual census alone was expected [29-31], the complementary characteristic of these methods and the degree of effectiveness when they were combined were revealed by the present data. The species recorded by the DVT method and SAM showed a significant difference in all species trait compositions (Table 3). A similar comparison of species trait compositions between these methods was not done before. The DVT species were, on average, significantly larger and more distant to the bottom or surface of the cliff. The DVT method also recorded occasional species, not found by SAM. The significantly different trophic levels recorded between methods were caused by the wider trophic distribution of DVT-recorded species compared to the SAM-recorded species. The DVT method revealed more omnivorous and herbivorous species at the lower trophic levels, as well as a number of species with a trophic level above 4 , not present in any of the SAM-recorded species. The DVT method had prevailingly species catchable by fishing tools, while the majority of SAM species were not possible to collect by any conventional fishing method. SAM also covered significantly more poorly known and elusive species compared to the DVT method, revealed indirectly by the later century of species description. SAM, compared to DVT species composition, showed different species composition by taxonomy on the taxon level of order. Therefore, the analysis of species traits showed in which way and to what degree SAM has complementary species composition to the DVT method; SAM targeted smaller, hidden species not collectible by any conventional method and, therefore, elusive, mostly belonging to different taxonomical orders than DVT species. With just two real inhabitants of infralittoral reefs found independently of the two methods, the combination of DVT 
and SAM was shown to be an efficient tool in estimating total fish species richness on coralligenous cliffs.

The number of species found on a single coralligenous cliff during this study by combining methods is clearly higher than that found during previous single-method studies $[7,8,12]$ when $35-46,43$, and 45 species were identified, respectively. Moreover, the number is higher even compared to studies from the Adriatic Sea $[11,32,33]$ where 51, 39 , and 33 species were reported, respectively. The most significant difference regarding species composition between this and previous studies is in the recorded number of species belonging to Gobiidae, Blennidae, and Gobiesocidae families (17, 5, and 2 species, respectively). Thus, this study shows that, when the aim is to determine total fish species richness of the marine complex habitat, relying on only one method results in more or less a significant underestimation of species richness, depending on the complexity of the investigated habitat. The incomplete and inaccurate registration of the fish community composition affects the efficiency of conservation planning and the implementation of appropriate conservation plans, which can be, consequently, inadequate and deficient.

The results of this study demonstrate that the combined use of the methods is essential for a better description of the whole fish community structure and for more accurate estimates of the abundance and diversity patterns, particularly in complex habitats such as coralligenous cliffs. Only when a community is completely known, further actions can be conducted to fully understand its trophic structure and ecosystem functioning. Furthermore, having precise and complete data on community structure is essential to define monitoring schemes required for the assessment of the conservation status of these highly sensitive and threatened Mediterranean marine habitats, especially related to potential changes in species structure and composition in reaction to multiple threats.

Author Contributions: Conceptualization, A.S. and M.K.; methodology, A.S., I.G. and M.K.; software, M.K.; validation, A.S., I.G. and M.K.; formal analysis, A.S. and M.K.; investigation, A.S., I.G. and M.K.; resources, A.S., I.G. and M.K.; data curation, A.S., I.G. and M.K.; writing-original draft preparation, A.S.; writing-review and editing, A.S., I.G. and M.K.; visualization, A.S.; supervision, A.S. and M.K.; project administration, A.S. All authors have read and agreed to the published version of the manuscript.

Funding: This research received no external funding.

Institutional Review Board Statement: This study was conducted according to the guidelines of the Declaration of Helsinki and approved by the Ministry of Environmental Protection and Nature (Class: UP/I-612-07/13-33/131; No. 517-07-1-1-2-13-4, from 18 October 2013).

Informed Consent Statement: Not applicable.

Data Availability Statement: The data presented in this study are available on request from the corresponding author.

Conflicts of Interest: The authors declare no conflict of interest.

\section{References}

1. Piazzi, L.; Balata, D.; Cecchi, E.; Gennaro, P.; Serena, F. Effectiveness of different investigation procedures in detecting anthropogenic impacts on coralligenous assemblages. Sci. Mar. 2014, 78, 319-328. [CrossRef]

2. European Commission. Water Framework Directive 2000/60/EC of the European Parliament and of the Council, of 23 October 2000, Establishing a Framework for Community Action in the Field of Water Policy; Official Journal of the European Commission, 22/12/2000, L 327; European Commission: Brussels, Belgium, 2000.

3. European Commission. MSFD 2008/56/EC of the European Parliament and of the Council, of 17 June 2008, Establishing a Framework for Community Action in the Field of Marine Environmental Policy (Marine Strategy Framework Directive); Official Journal of the European Commission, G.U.C.E. 25/6/2008, L 164/19; European Commission: Brussels, Belgium, 2008.

4. Bracchi, V.; Savini, A.; Marchese, F.; Palamara, S.; Basso, D.; Corselli, C. Coralligenous habitat in the Mediterranean Sea: A geomorphological description from remote data. Ital. J. Geosci. 2015, 134, 32-40. [CrossRef]

5. Ballesteros, E. Mediterranean coralligenous assemblages: A synthesis of present knowledge. Oceanogr. Mar. Biol. Ann. Rev. 2006, 44, 123-195. 
6. Piazzi, L.; Gennaro, P.; Cecchi, E.; Bianchi, C.N.; Cinti, M.F.; Gatti, G.; Guala, I.; Morri, C.; Sartoretto, F.; Serena, F.; et al. Ecological status of coralligenous assemblages: Ten years of application of the ESCA index from local to wide scale validation. Ecol. Indic. 2021, 121, 107077. [CrossRef]

7. Piazzi, L. Large-scale patterns in species composition of coralligenous fish assemblages. Vie Milieu 2016, 66, 121-127.

8. Piazzi, L.; Cecchi, E.; Serena, F. Spatial and temporal patterns of diversity in Mediterranean rocky reef fish assemblages. Vie Milieu 2012, 62, 129-136.

9. Warnock, B.; Harvey, E.S.; Newman, S.J. Remote drifted and diver operated stereo-video systems: A comparison from tropical and temperate reef fish assemblages. J. Exp. Mar. Biol. Ecol. 2016, 478, 45-53. [CrossRef]

10. Patzner, R.A. Habitat utilization and depth distribution of small cryptobenthic fishes (Blenniidae, Gobiidae, Trypyterigiidae) in Ibiza (western Mediterranean Sea). Environ. Biol. Fish. 1999, 55, 207-214. [CrossRef]

11. Soldo, A.; Glavičić, I. Underwater Visual Census of Deeper Vertical Rocky Reefs. Turk. J. Fish. Aquat. Sci. 2020, 20, 785-794. [CrossRef]

12. Spanier, E.; Pisanty, S.; Tom, M.; Almog-Shtayer, G. The fish assemblage on a coralligenous shallow shelf off the Mediterranean coast of northern Israel. J. Fish Biol. 1989, 35, 641-649. [CrossRef]

13. Colton, M.A.; Swearer, S.E. A comparison of two survey methods: Differences between underwater visual census and baited remote underwater video. Mar. Ecol. Prog. Ser. 2010, 400, 19-36. [CrossRef]

14. Pyle, R.L.; Earle, J.L.; Greene, B.D. Five new species of the damselfish genus Chromis (Perciformes: Labroidei: Pomacentridae) from deep coral reefs in the tropical western Pacific. Zootaxa 2007, 1671, 15-18. [CrossRef]

15. Glavičić, I.; Paliska, D.; Soldo, A.; Kovačić, M. A quantitative assessment of the cryptobenthic fish assemblage at deep littoral cliffs in the Mediterranean. Sci. Mar. 2016, 80, 3-329. [CrossRef]

16. Ackerman, J.L.; Bellwood, D.R. Reef fish assemblages: A re-evaluation using enclosed rotenone stations. Mar. Ecol. Prog. Ser. 2000, 206, 227-237. [CrossRef]

17. Willis, T.J. Visual census methods underestimate density and diversity of cryptic reef fishes. J. Fish Biol. 2001, 59, 1408-1411. [CrossRef]

18. Kovačić, M.; Patzner, R.A.; Schliewen, U.K. A first quantitative assessment of the ecology of cryptobenthic fishes in the Mediterranean Sea. Mar. Biol. 2012, 159, 2731-2742. [CrossRef]

19. Glavičić, I.; Kovačić, M. A quantitative sampling method for assessment of deep cryptobenthic ichthyofauna using trimix diving. Acta Ichthyol. Piscat. 2016, 46, 43-47. [CrossRef]

20. Sokal, R.R.; Rohlf, F.J. Biometry: The Principles and Practice of Statistics in Biological Research, 3rd ed.; W.H. Freeman and Co.: New York, NY, USA, 1995; p. 887.

21. Froese, R.; Pauly, D. (Eds.) FishBase. World Wide Web Electronic Publication. 2021. Available online: www.fishbase.org (accessed on 15 May 2021).

22. Pauly, D.; Froese, R.; Palomares, M.L.; Stergiou, K.I.; Apostolidis, C. Fish on Line. A Guide to Learning and Teaching Ichthyology using the FishBase Information System. Version 3. 2014. Available online: https://www.fishbase.se/fishonline/english/index. htm (accessed on 15 May 2021).

23. Dulčić, J.; Kovačić, M. The Adriatic Sea Ichthyofauna; Split, Golden Marketing, Tehnička Knjiga i Institut za Oceanografiju i Ribarstvo: Zagreb, Croatia, 2020; p. 677. (In Croatian)

24. Van der Laan, R.; Fricke, R.; Eschmeyer, W.N. (Eds.) Eschmeyer's Catalog of Fishes: Classification. 2021. Available online: http:/ / www.calacademy.org/scientists/catalog-of-fishes-classification/ (accessed on 12 May 2021).

25. McDonald, J.H. Handbook of Biological Statistics; Sparky House Publishing: Baltimore, MD, USA, 2014; p. 296.

26. Hammer, Ø.; Harper, D.A.T.; Ryan, P.D. PAST: Paleontological Statistics Software Package for Education and Data Analysis. Palaeontol. Electron. 2001, 4, 9. Available online: http://palaeo-electronica.org/2001_1/past/issue1_01.htm (accessed on 15 May 2021).

27. La Mesa, G.; Molinari, A.; Gambaccini, S.; Tunesi, L. Spatial pattern of coastal fish assemblages in different habitats in Northwestern Mediterranean. Mar. Ecol. 2010, 32, 104-114. [CrossRef]

28. Garcia-Charton, J.A.; Williams, I.; Perez-Ruzafa, A.; Milazzo, M.; Chemello, R.; Marcos, C.; Kitsos, M.-S.; Koukouras, A.; Riggio, S. Evaluating the ecological effects of Mediterranean marine protected areas: Habitat, scale and the natural variability of ecosystems. Environ. Conserv. 2000, 27, 159-178. [CrossRef]

29. Sale, P.F.; Douglas, W.A. Precision and accuracy of visual census technique for fish assemblages on coral patch reefs. Environ. Biol. Fishes 1981, 6, 333-339. [CrossRef]

30. Beldade, R.; Goncalves, E.J. An interference visual census technique applied to cryptobenthic fish assemblages. Vie Milieu 2007, 57, 61-65.

31. Alzate, Z.F.A.; Giraldo, A. A comparison of visual and collection-based methods for assessing community structure of coral reef fishes in the Tropical Eastern Pacific. Rev. Biol. Trop. 2014, 62 (Suppl. 1), 359-371. [CrossRef]

32. Casellato, S.; Stefanon, A. Coralligenous habitat in the northern Adriatic Sea: An Overview. Mar. Ecol. 2008, $29,321-341$. [CrossRef]

33. Fasola, M.; Canova, L.; Foschi, F.; Novelli, O.; Bressan, M. Resource use by a Mediterranean rocky slope fish assemblage. Mar. Eco. 1997, 18, 51-66. [CrossRef] 